\title{
A critical review of the effect of factory closures on health
}

\author{
J K Morris, D G Cook
}

\begin{abstract}
The dramatic rise in unemployment in the 1970s and 1980s has led to an increase in research into the possible effects of unemployment on health. Studies of the effects of job loss are difficult to interpret because of the difficulty in ruling out selection effects-for example, the least fit may be more likely to be made redundant. The study of factory closures is appealing since all employees are made redundant and all the studies of factory closure recorded in the Index Medicus since 1980 are reviewed. None of the studies fulfil all the criteria for an ideal study, and most fail on several counts. The small sample sizes are often unavoidable, but the lack of awareness of possible selection effects often results in a biased control group of only those people who are economically active. Also, the short duration of follow up restricts the detection of possible long term effects on health. Thus the conclusions that can be drawn about the health effects of factory closures are limited. Whereas there is evidence of short term effects on mental health and of increased use of primary health care, no long term effects have been studied and objective data on physical health are almost non-existent.
\end{abstract}

The 1980s saw a dramatic rise in the unemployment rates in most western countries. In the United Kingdom the number of people registered as unemployed reached a peak at 3.2 million in August $1986 .{ }^{1}$ Whereas links between the working environment and the physical ill health of the workers have long been established, the evidence for the effects of unemployment on health, particularly physical health, is not so definite. The major problem is that although unemployed people do tend to be less healthy, ${ }^{2345}$ it may be that their health contributes to the likelihood of their becoming unemployed.

Department of Public Health and Primary Care, Royal Free Hospital School of Medicine, London NW3 2PF

J K Morris, D G Cook
The advantages of using factory closures to study the effects of redundancy on health are:

(1) There is no self selection-all the people followed up are made unemployed through no fault of their own and they all start off from being employed (usually full time).

(2) Most subjects may have been in stable employment for many years. Analysis restricted to such people avoids the need to consider the effects of preceding unemployment.

(3) If measurements are made before closure, "before and after" analysis can be done, and the changes due to redundancy examined.

The disadvantages are:

(1) The populations studied are fairly homogeneous, often just men who are manual workers.

(2) The people studied are likely to be reasonably healthy (the healthy worker effect).

(3) Two different effects are being examinedthe effect of being made redundant and also the effect of either being unemployed or adapting to a new job.

(4) The job loss experience is of a specific type and different from being fired in that the degree of self recrimination is lower (previous studies suggest that self blame may be an important prelude to other adverse effects). ${ }^{6}$

(5) Often the factory concerned will be the main employer in a small area and so the experiences of unemployment are different from those if the unemployment was affecting the whole community. ${ }^{7}$

(6) The self selection bias cannot be eliminated when looking at the severity of the job loss experience, as the less healthy employees may find it harder to get a new job.

(7) Any control group is unlikely to be directly comparable, as it will be selected from a different factory.

(8) The numbers in such studies are restricted to the people working in the factory who satisfy the inclusion criteria.

The aim of this paper is to review all studies on the effects of factory closures on health referenced by Index Medicus since 1980. In the next section a brief description is given of each study, with two tables summarising the pertinent features of the study designs. Subsequent sections consider the adequacy 
of the study designs, the measurements of health collected, and the statistical analysis of these measurements. Then we present sections on the effects of closure of factories on physical and mental health, use of the health service, and other health related behaviour.

\section{The studies}

MICHIGAN (UNITED STATES) 689

This is the earliest study reported (field work carried out in 1967). The aim was to investigate the health and behavioural effects of job loss and of the ensuing unemployment or experience of change of job or both. The mental and physical health of men from two manufacturing plants that were due to close was measured before closure and several times afterwards. The health of the employees was compared with the health of employees in matched control factories. Local unemployment was low, so there was a high rate of re-employment.

\section{DANISH FACTORY ${ }^{10}$}

The use of medical services was examined in a group of Danish factory workers in the year before and the year after they were made redundant. No control group was included.

\section{SARDINE FACTORY (NORWAY) 1112}

The effects of a factory closure in Norway on sick leave in the first year after closure (unemployed people in Norway can also claim sick leave) and the receipt of disability pensions over the subsequent 10 years was assessed. A control group of workers from a similar neighbouring factory was included. The study had the advantage that the two end points were measured from general practitioners' notes and were, therefore, not self reported. Also sick leave in the year before closure could be measured.

\section{NORDHAVN (DENMARK) 131415}

The original aim was to investigate how shipyard workers perceived the health hazards of the job. Therefore various measurements were made before there was any knowledge about the closure. Once the closure was announced, it was then decided to follow up the workers for three years to investigate the effects on the workers' health. No control group was included.

\section{NEWSPAPER (LONDON, ENGLAND) ${ }^{16}$}

The original aim was to investigate the prevalence of minor psychiatric morbidity in professionals (journalists) facing the threat of redundancy and to determine how the prevalence altered once redundancy occurred. The initial measurements were made after the redundancy notices were received. These notices were then retracted, however, and further measurements were made. The final measurements were made three months later when the threat of redundancy had been removed. The response rate was low (about $35 \%$ ) and this limits the conclusions that can be drawn from this study. No control group was included.

\section{SKF (TORONTO, CANADA) $)^{17}$}

The aim was to investigate the stress attributed to the closure of a factory and the effects on the employees' health. Data were collected before the actual closure but when the closure was known about, and for up to two years after. Detailed analysis was restricted to the small number of men for whom complete data were available. No control group was included.

\section{CALNE (WILTSHIRE, ENGLAND) ${ }^{18-26}$}

The effects of a factory closure on general practice consultation rates were examined. Data two years before any knowledge about the closure were available. The employees and a comparable control group were followed up for 10 years. The employees were those people who were still employed at the Calne factory in 1982. There were only 302 employees in 1982 compared with an initial workforce of 886 in 1979 and thus these employees may not have been representative of the original workforce. Subjects were excluded from the control group if they became economically inactive. Because similar people were not excluded from the study group this is likely to lead to bias. Unfortunately the inappropriate statistical analyses also limit the conclusions that can be drawn.

\section{ELSINORE (DENMARK) 132728}

There were two separate aims to this study and for the purpose of this paper it is treated as two separate studies, although in fact it was one shipyard that closed down. In Elsinore 1 the effects of the closure on health were examined using annual postal questionnaires in the three years after closure. In Elsinore 2 the numbers of admissions to hospital were examined in the five years before and the three years after closure. For both studies control groups were included. In Elsinore 2 subjects who became economically inactive were excluded from the analysis. This is likely to be a source of bias due to the relation observed in other studies of unemployed people being more likely to become economically inactive. ${ }^{29}$ 
CGE (TORONTO, CANADA) 30

The health of former employees of a Canadian General Electric factory in the three to 27 months after closure was assessed by comparing their answers to the Canada Health Survey questionnaire with the answers given by the economically active population of Ontario.

SMITH'S DOCK (MIDDLESBROUGH, ENGLAND) ${ }^{31} 32$

The aim was to examine the effect of the closure of the shipyard on the workforce in terms of their subsequent employment, finances, mental health, and wellbeing. A representative sample of the workforce was interviewed six times in the year after closure. No control group was included.

\section{Study design}

Tables 1 and 2 summarise the main design features of the 10 studies. Only two had a study population greater than 130 employees and only four had relevant control populations (the economically active population of Ontario does not appear to be a strictly comparable control population to the employees in the CGE study). In the Calne study economically inactive subjects were excluded from the control group and in Elsinore 2 they were excluded from the study and control groups, causing bias in both.
The studies were of two types. In the first group (Sardine factory, Calne, Danish factory, Elsinore 2) the employees' medical records were examined and the employees were not directly implicated. The response rate in these studies was high. Also, measurements were obtained on the employees before they had knowledge of the impending closure (referred to in table 2 as the "pre-closure" time, as opposed to the "anticipatory" time when the closure had been announced but had not yet occurred).

In the second group (Michigan, Nordhavn, Newspaper, SKF, Elsinore 1, CGE, Smith's Dock) the employees were directly consulted. The response rate was variable. Generally no information about the employees was available before knowledge about the impending closure. The Nordhavn study was the exception, because it was set up to investigate health hazards of the job. The later announcement of the shipyard closure was totally unexpected, and it was decided then to follow up the men to investigate the effects of the closure.

In all the studies on the effect of redundancy over time, the numbers analysed are those employees who had not been lost to follow up. The response rates given in table 1 include the effects of loss to follow up. This was generally much smaller than the initial nonresponse as the follow up period was very short, with only two studies having a follow up of longer than three years (Sardine factory and Calne) and three

Table 1 Design features of factory closures

\begin{tabular}{|c|c|c|c|c|c|c|c|c|}
\hline Factory name & Study name & $\begin{array}{l}\text { Date of } \\
\text { closure }\end{array}$ & of factory & $\begin{array}{l}\text { Local } \\
\text { unemploy- } \\
\text { ment }\end{array}$ & Study population & $\begin{array}{l}\text { No in } \\
\text { survey }\end{array}$ & $\begin{array}{l}\text { Response } \\
\text { rate }(\%)\end{array}$ & $\begin{array}{l}\text { Controls }(R R= \\
\text { response rate) }\end{array}$ \\
\hline $\begin{array}{l}\text { Michigan } \\
\text { factories }\end{array}$ & Michigan & 1967 & $\begin{array}{l}\text { Four manufacturing } \\
\text { plants; one rural, one } \\
\text { urban }\end{array}$ & Low & $\begin{array}{l}\text { Male blue collar workers, } \\
\text { married and aged } 35-60 \text {, } \\
\text { with more than three years } \\
\text { job tenure }\end{array}$ & 100 & 70 & $\begin{array}{l}74 \text { comparable men at } \\
\text { four urban/rural } \\
\text { factories }(R R=68 \%)\end{array}$ \\
\hline $\begin{array}{l}\text { Unnamed Danish } \\
\text { factory }\end{array}$ & Danish factory & 1971 & Unknown & & $\begin{array}{l}\text { Job tenure } \\
\text { Men }\end{array}$ & 43 & 58 & None \\
\hline $\begin{array}{l}\text { Norbest Canning } \\
\text { Co }\end{array}$ & Sardine factory & Jan 1975 & Sardine factory & Low & $\begin{array}{l}72 \text { men, } 13 \text { women (part } \\
\text { time, and full time) }\end{array}$ & 85 & 100 & $\begin{array}{l}21 \text { men, } 66 \text { women } \\
\text { from NC factory in } \\
\text { Davenger (RR = } \\
100 \%)\end{array}$ \\
\hline $\begin{array}{l}\text { Nordhavn } \\
\text { shipyard }\end{array}$ & Nordhavn & Dec 1976 & Shipyard & High & Skilled men & 87 & 87 & None \\
\hline $\begin{array}{l}\text { Newspaper } \\
\text { redundancies }\end{array}$ & Newspaper & Dec 1980 & Newspaper & High & $\begin{array}{l}\text { Journalists; men and } \\
\text { women }\end{array}$ & 111 & 35 & None \\
\hline SKF Canada & SKF & Dec 1981 & Bearings factory & High & Male blue collar workers & 45 & 15 & None \\
\hline $\begin{array}{l}\mathrm{C} \text { and T Harris } \\
\text { (Calne) Ltd }\end{array}$ & Calne & July 1982 & Meat manufacturers & Low & $\begin{array}{l}\text { Men and women (full time) } \\
\text { who had }>\text { four years } \\
\text { tenure, made redundant } \\
\text { June } 1982 \text {. Social classes } \\
3,4 \text {, and } 5\end{array}$ & 129 & 100 & $\begin{array}{l}99 \text { employees } \\
\text { continuously working } \\
\text { at similar factory. } \\
(\mathrm{RR}=100 \%)\end{array}$ \\
\hline Elsinore shipyard & Elsinore 1 & 1983 & Shipyard & High & $\begin{array}{l}\text { Men with > } 6 \text { months } \\
\text { seniority }\end{array}$ & 1001 & 60 & $\begin{array}{l}448 \text { men employed at } \\
\text { Danneborg shipyard } \\
6 \text { months }(\mathrm{RR}=82 \%)\end{array}$ \\
\hline Elsinore shipyard & Elsinore 2 & 1983 & Shipyard & High & $\begin{array}{l}\text { Men with > } 6 \text { months } \\
\text { seniority and economically } \\
\text { active }\end{array}$ & 887 & 67 & $\begin{array}{l}441 \text { men employed at } \\
\text { Danneborg shipyard } \\
6 \text { months and } \\
\text { economically active } \\
(\mathrm{RR}=82 \%)\end{array}$ \\
\hline $\begin{array}{l}\text { Canadian } \\
\text { General Electric } \\
\text { factory }\end{array}$ & CGE & $\begin{array}{l}\text { March } \\
1984\end{array}$ & General electric & High & $\begin{array}{l}\text { Skilled workers (men and } \\
\text { women) }\end{array}$ & 124 & 31 & Population of Ontario \\
\hline Smith's Dock & Smith's Dock & Feb 1987 & Shipyard & High & Men; $80 \%$ manual workers & 200 & 100 & None \\
\hline
\end{tabular}


Table 2 Timing and type of data collected

\begin{tabular}{|c|c|c|c|c|c|c|c|c|c|c|c|c|}
\hline \multirow[b]{2}{*}{$\begin{array}{l}\text { Study } \\
\text { name }\end{array}$} & \multicolumn{5}{|c|}{ Time of data collection } & \multicolumn{7}{|c|}{ Type of data collected } \\
\hline & $\begin{array}{l}\text { Pre- } \\
\text { closure }\end{array}$ & $\begin{array}{l}\text { Antici- } \\
\text { patory }\end{array}$ & $\begin{array}{l}0-12 \\
\text { months }\end{array}$ & $\begin{array}{l}1-3 \\
\text { years }\end{array}$ & $\begin{array}{l}>3 \\
\text { years }\end{array}$ & $\begin{array}{l}\text { Self } \\
\text { assessed }\end{array}$ & $\begin{array}{l}\text { Clinical } \\
\text { examination }\end{array}$ & $G H Q$ & $\begin{array}{l}\text { Health } \\
\text { service } \\
\text { use }\end{array}$ & Tobacco & Alcohol & $\begin{array}{l}\text { Other } \\
\text { measures }\end{array}$ \\
\hline Michigan & No & Yes & Yes & Yes & No & Yes & Yes & No & No & Yes & No & $\begin{array}{l}\text { Sick role } \\
\text { behaviour }\end{array}$ \\
\hline Danish factory & Yes & Yes & Yes & No & No & No & No & No & GP visits & No & No & \\
\hline Sardine factory & Yes & Yes & Yes & Yes & Yes & No & No & No & No & No & No & $\begin{array}{l}\text { Sick leave } \\
\text { disability } \\
\text { pensions }\end{array}$ \\
\hline Nordhavn & Yes & No & Yes & Yes & No & Yes & Yes & No & $\begin{array}{l}\text { GP visits } \\
\text { drug use }\end{array}$ & Yes & Yes & \\
\hline Newspaper & No & Yes & No & No & No & Yes & Yes for $60 \%$ & Yes & No & No & Yes & \\
\hline SKF & No & Yes & Yes & Yes & No & Yes & No & No & $\begin{array}{l}\text { GP visits } \\
\text { drug use }\end{array}$ & No & No & \\
\hline Calne & Yes & Yes & Yes & Yes & Yes & No & No & No & $\begin{array}{l}\text { GP and } \\
\text { hospital visits }\end{array}$ & No & No & Sick leave \\
\hline Elsinore 1 & No & No & Yes & Yes & No & Yes & No & Yes & No & No & No & $\begin{array}{l}\text { Chest pain } \\
\text { questionnaire }\end{array}$ \\
\hline Elsinore 2 & Yes & Yes & Yes & Yes & No & No & No & No & $\begin{array}{l}\text { Hospital } \\
\text { admissions }\end{array}$ & No & No & \\
\hline CGE & No & No & Yes & Yes & No & Yes & No & No & No & No & No & \\
\hline Smith's Dock & No & No & Yes & No & No & Yes & No & Yes & No & Yes & Yes & \\
\hline
\end{tabular}

studies having a follow up of one year or less. In Elsinore 2 the effects of loss to follow up were estimated and were concluded to be negligible.

\section{Health measures}

Only two studies clinically examined the employees (Michigan and Nordhavn); the rest relied on either the employees' self reported health or else the employees' use of the health service as a measure of morbidity. The General Health Questionnaire (GHQ) was used in three studies (Newspaper, Elsinore 1 and Smith's Dock) to measure psychiatric morbidity. Although it is self administered it has been shown to be a reliable method of measuring psychiatric morbidity. In the Sardine Factory study the claiming of disability pensions was examined. Even though a medical certificate had to be obtained before a subject could claim, the presence of strong financial incentives meant that this measure could not be assumed to be directly related to the morbidity of the employees. Some of the observed differences in health between the study and control groups may have been due to different rates of smoking and alcohol consumption, but only three studies measured alcohol consumption (Nordhavn, Newspaper, and Smith's Dock) and only three measured the levels of smoking (Michigan, Nordhavn, and Smith's Dock).

\section{Statistical analyses}

The small sample sizes and lack of controls (see table
1) restricted the types of analysis. In several studies the lack of controls was overcome by comparing the employees before and after closure. In most, however, the lack of data before knowledge of redundancies (the "pre-closure" period in table 2), meant that the baseline data were collected when the employees knew that the factory was going to close (the "anticipatory" period) and so was affected by their anticipation of redundancy. In several studies a separate problem arose after redundancy, when the health of the employees who regained employment was compared with that of those who did not (Nordhavn, Michigan, Elsinore 1). Any differences detected may have been due to healthier people finding it easier to get a new job, rather than the effects of unemployment.

In the Calne study several faults in the analysis limit the conclusions that can be drawn. Despite having an excellent control group no formal comparison of the changes in consultation rates observed in the study group was made with that observed in the control group. A second flaw arises in several of the later papers where subjects were excluded from the control group if they became economically inactive. As similar people were not excluded from the study group this is likely to lead to bias. In particular, it may explain the fall in consultation rates in the control group as the group got older. Finally, whereas statistical testing was carried out using nonparametric methods, due to the skewness of the distribution of consultation rates, the data were presented as percentage increases; this is potentially misleading. 
Effects of factory closure on physical health In the Calne study the number of chronic episodes of illness per 100 patients per year rose significantly from $9 \cdot 2$ originally, to 18.4 in the anticipatory phase, to 24.7 after the redundancies had occurred. The control employees had non-significant changes of $14 \cdot 9$, to $18 \cdot 8$, to $17 \cdot 4$, but no formal comparisons of the two groups were made (a chronic episode of illness was defined as an episode still requiring active medical management more than one year after presentation). In the Michigan study in the anticipatory phase the mean serum uric acid concentrations were significantly higher for the employees than for the control group. On gaining reemployment these concentrations fell, indicating that the higher concentrations were due to the anticipation of the factory closure. Changes in consumption of alcohol could also account for these changes but no data on alcohol consumption were collected.

Any detrimental effects of factory closure must be balanced against the possible health hazards of the job. The health of the employees in the Elsinore 2 study seemed to improve, because the relative risk of admission to hospital in the study group compared with the controls fell significantly from 1.29 four to five years before closure to 0.74 three years afterwards. This was because the relative risk of accidents and diseases of the digestive system fell ( 1.33 to 0.46 and 4.53 to 1.03 ), whereas the relative risks of circulatory and cardiovascular diseases increased $(0.8$ to 1.60 and 1.0 to 2.6 ). The change in admissions was interpreted as being a result of exchanging the high health risks in the work environment for the health effects of stress due to unemployment and job insecurity. Some of the change in relative risk, however, was due to the increase in admissions for accidents and diseases of the digestive system in the control group. Moreover, there was no allowance for any changes in consumption of alcohol and smoking that might have altered the risk, particularly for diseases of the digestive system.

An effect of stress on physical health was also claimed in the Michigan study, where the ulcer activity of the study population was significantly higher than that of the control population (14 days per 1000 person days $v 0 \cdot 8$ days). Again there were no data available on consumption of alcohol. The amount of cigarette smoking did not change.

A further problem with ulcer activity is that it is self reported and it may be that the unemployed report more diseases. This was suspected in the CGE study where three months after the factory closed the study population reported suffering significantly more ailments than the control population (an average of 2.3 ailments $v 1.05$ ). The illnesses were not all stress related (for example, eyesight problems) and were unlikely to have developed in only three months. Also the study population was made up of middle class men who would usually be assumed to be more healthy than the control population.

The health effects may also be mitigated or ameliorated by the subsequent employment experiences of the subject. In the Nordhavn study the employees who subsequently experienced the greatest amount of unemployment actually showed an improvement in chronic bronchitis and functional heart troubles. In general, however, the problem with comparing employees who subsequently find work with those who remain unemployed for longer is that there is a strong health selection effect, with the fittest finding jobs first (the SKF study and the Michigan study). In the Michigan study $53 \%$ of the employees who subsequently experienced the greatest amount of unemployment had raised blood sugar concentrations compared with $8 \%$ for the employees experiencing least unemployment. This means that any differences in health between those that find employment and those that do not is not readily attributable to the effects of unemployment. This is important when interpreting the findings of the Elsinore 1 study in which the prevalence of various symptoms in the unemployed (from both the study and the control population) was compared with the prevalence in the employed (from both populations). The prevalence of hypertension, dyspnoea, and chest pain was significantly higher in the unemployed (the relative prevalence proportions were $2.08,1.49$, and 1.51 ). To overcome this problem in the Nordhavn study the use of medicine before closure is given for both the men who subsequently experienced less employment and those who experienced more, to show that both groups were similar before closure $28 \%$ and $27 \%$ reported taking medicines) whereas after two years the percentages were significantly different $(31 \%$ and $57 \%)$.

\section{Effects of factory closure on mental health}

Three studies measured psychiatric morbidity using the GHQ. The Smith's Dock and Elsinore 1 study found a strong relation between the current employment state after the closure had occurred and the current GHQ score, with higher scores indicating greater morbidity. In the Elsinore 1 study, one year after the closure the odds ratio of having a score higher than 15 (15 being an arbitrary cut off point chosen by the authors) was 2.48 for the men who were unemployed compared with those who were employed. The Smith's Dock study indicates that this difference is not solely due to a self selection effect, because on finding re-employment the employees' GHQ score dropped. The Newspaper study found that just the threat of redundancy had an adverse effect on the GHQ score. On learning that their jobs were no longer under threat the prevalence of "cases" (judged from the GHQ scores) decreased significantly from $37 \%$ to $24 \%$. 
The Nordhavn study considered the prevalence of a combination of mental symptoms that included nervousness, tiredness, and depression, and compared those who subsequently experienced the least unemployment with those who subsequently experienced the most. The prevalence was $40 \%$ in both groups before knowledge of the closure, but two years later the prevalence was $29 \%$ for those who had experienced the least unemployment and $47 \%$ for those who had experienced the most.

Two studies (SKF, CGE) that were concerned about stress resulting from the factory closure attempted to measure it by scoring three questions:

(1) The person's feelings on how much the closure bothered him.

(2) Assessments about how long it was before things returned to normal.

(3) Rankings of the stress generated by the closure as a life event.

Although both studies showed that the employees had very high scores, no control group comparison was possible.

Effects of factory closure on general practitioner consultation rates

The number of times someone consults their general practitioner is affected by other factors as well as their actual health. Out of the three studies that reported general practitioner consultation rates, two studies report an increase in consultation rates which starts to occur in the anticipatory phase (Danish factory and Calne) and the other study reports no difference in consultation rates (Nordhavn). The reason for this may be due to the fact that in the Danish factory and Calne studies the general prac- titioners' notes were examined, whereas in the Nordhavn study the consultation rates were obtained using a retrospective questionnaire. Alternatively there may be no overall effect on the consultation rate of shipyard workers just as there was no overall effect on the hospital admission rate for the shipyard workers in Elsinore 2.

The Calne study examines the factors affecting consultation rates in the greatest detail. The conclusions that can be drawn, however, are limited by several flaws in the analysis. For completeness, table 3 , which summarises some of their findings, is included but it should be interpreted with caution.

\section{Effects of factory closure on other health related behaviour}

In the Sardine factory study in the first year of follow up the employees claimed a significant excess of $2 \cdot 4$ disability pensions per 100 persons more than the control group. This continued to increase to an excess of 17.9 pensions per 100 persons by the end of the fourth year, after which it levelled off. Although a medical certificate is required, there is also more incentive for an unemployed person to claim disability pension rather than unemployment benefit. These long term effects may also arise because even if new employment is found it is often inferior to the previous job and more likely to be temporary. This means that the men who find new employment are often subjected to several more periods of unemployment. This is apparent in the Nordhavn study where increasingly more men withdrew from the labour market (3\% were economically inactive in the first year, rising to $28 \%$ by the end of the third year), preferring to be classified as retired or sick.

Table 3 Percentage increases in consultation rates (Calne study) during anticipatory phases, lost phases, or both compared with consultation rates at time of stable employment $(E=$ employees, $C=$ controls, $U=$ unknown)

\begin{tabular}{|c|c|c|c|c|c|c|}
\hline \multirow[b]{2}{*}{ Group } & \multicolumn{2}{|c|}{$\begin{array}{l}\text { Anticipatory } \\
\text { and lost }\end{array}$} & \multicolumn{2}{|c|}{ Anticipatory } & \multicolumn{2}{|l|}{ Lost } \\
\hline & $E$ & $C$ & $E$ & $C$ & $E$ & $C$ \\
\hline $\begin{array}{l}\text { Men aged }<40 \\
\text { Men aged } 41-60 \\
\text { Men aged } 61-64 \\
\text { Women aged }<35 \\
\text { Women aged } 36-55 \\
\text { Women aged 56-59 } \\
\text { Married men: } \\
\quad \text { Aged 52-64 } \\
\text { Aged 26-51 } \\
\text { Long job tenure } \\
\text { Short job tenure } \\
\text { Sole employment } \\
\text { Previous employment elsewhere } \\
\text { All employees in study } \\
\text { Employees subsequently experiencing } \\
\text { greatest unemployment (matched for age } \\
\text { and sex) }\end{array}$ & $\begin{array}{l}-18 \\
48^{\star \star} \\
140^{\star}\end{array}$ & $\begin{array}{l}-24 \\
-10 \\
U\end{array}$ & $\begin{array}{l}22 \\
52^{\star} \\
8 \\
30 \\
23^{\star} \\
45^{\star}\end{array}$ & $\begin{array}{l}\mathrm{U} \\
\mathrm{U} \\
\mathrm{U} \\
-18 \\
-3\end{array}$ & $\begin{array}{l}105^{\star} \\
7 \\
76^{\star} \\
-6 \\
20 \\
57^{\star}\end{array}$ & $\begin{array}{l}\mathrm{U} \\
\mathbf{U} \\
\mathbf{U} \\
\mathbf{U} \\
-22^{\star} \\
-20\end{array}$ \\
\hline
\end{tabular}


The financial advantages of being certified sick rather than being unemployed may account for some of the $41 \%$ increase in sick leave experienced by the employees in the Sardine factory study in the first year after the closure. It does not explain the significant increase in the duration of certificated sick leave for the employees in the Calne study of an average of nine days in the stable employment period to 13 days when jobs were threatened.

\section{Effects of factory closure on alcohol and tobacco consumption}

In both the Nordhavn and the Smith's Dock studies, the employees reported decreases in consumption of alcohol. In the Smith's Dock study $53 \%$ of the employees said they were spending less money on alcohol. In the Nordhavn study the odds ratio for a decrease in consumption of alcohol of the men who had remained unemployed $v$ those who regained employment was four $(p<0.012)$. In the Newspaper study, however, no change in alcohol consumption was reported. Several reasons could account for this apparent discrepancy. For instance, the incorrect analysis may have been carried out (the average distribution of consumption of alcohol is extremely skew). There may be no effect on alcohol consumption in the anticipatory phase or the monetary aspect induces lower consumption and journalists are wealthier than unemployed shipyard workers.

Similarly for smoking the employees in the Smith's Dock study reported spending 35\% less. The Michigan study found no change in smoking habits. This discrepancy might be due to the fact that smoking was a much more expensive habit in Great Britain in 1987 compared with the United States in 1967.

\section{Effects of factory closure on mortality}

None of the studies reported were large enough or had long enough follow ups to allow analysis of mortality data. The Michigan study mentions anecdotal evidence on suicides.

\section{Conclusions}

The ideal study design would encompass a large number of employees with a similar number of controls working in a similar factory; both study populations should have high response rates. The study would collect data before any knowledge about the closure and the data would consist of both self reported health and objective measures of health and health behaviour. The follow up would be for more than five years (ideally at least 10) and the loss to follow up would be small. None of the 10 studies discussed fulfil all the criteria for an ideal study, with most failing on several counts. Thus the conclusions that can be drawn about the health effects of factory closures are limited.

As there are no large studies with follow up for more than three years, no conclusions about the long term effects on health can be made; any effects on physical health are only likely to become apparent in the long term. The short term mental health of the employees was clearly adversely affected (measured by the GHQ); their mental health, however, appeared to improve on regaining employment. No evidence is forthcoming as to whether there was a lasting effect of long term unemployment on mental health. An increase in the frequency of use of the health service (measured by general practitioner consultation rates) for workers in low risk employment was found; when their jobs had higher physical risks (shipyard workers) the improvement in the risk of accidents offset any negative effects of unemployment (measured by hospital admission rates). The consumption of alcohol and tobacco decreased, probably due to the financial constraints of unemployment.

1 Department of Employment Gazette. 1987;7:533.

2 Moser KA, Fox AJ, Jones DR. Unemployment and mortality in the OPCS longitudinal study. Lancet 1984;ii:1324-8.

3 Cook DG, Cummins RO, Bartlet MJ, Shaper AG. Health of unemployed middle-aged men in Great Britain. Lancet 1982;i:1290-4.

4 Kessler RC, House JS, Turner JB. Unemployment and health in a community sample. J Health Soc Behav 1987;28:51-9.

5 D'Arcy C. Unemployment and health: data and implications. Can J Public Heath 1986;77:124-31.

6 Kasl SV. Strategies of research on economic instability and health. Psychological Medicine 1982;12:637-49.

7 Iversen L, Andersen O, Andersen PK, Christoffersen K, Keiding N. Unemployment and mortality in Denmark, 197080. Br Med $J$ 1987;295:879-84.

8 Cobb S, Kasl SV. The consequences of job loss. Cincinnati: US Department of Health, Education and Welfare, 1977. (NIOSH No 77-224).

9 Kasl SV, Cobb S, Gore S. Changes in reported illness and illness behaviour related to termination of employment: A preliminary report Int J Epidemiol 1972;1:111-8.

10 Jacobsen K. Dismissal and morbidity. Ugeskr Laeger 1972;134:352-4.

11 Westin S, Schlesselman JJ, Korper M. Long-term effects of a factory closure: unemployment and disability during ten years' follow-up. Journal of Clinical Epidemiology $1989 ; 42: 435-41$.

12 Westin S, Norum D, Schlesselman JJ. Medical consequences of a factory closure: illness and disability in a four-year follow-up study. Int J Epidemiol 1988;17:153-61.

13 Iversen L, Sabroe S. Plant closures, unemployment, and health: Danish experiences from the declining ship-building industry. In: Schwefel D, Svensen PG, Zollner H, eds. Unemployment, social vulnerability and health in Europe, SpringerVerlag, 1987:31-47.

14 Iversen $\mathrm{L}$, Klausen $\mathrm{H}$. Alcohol consumption among laid-off workers before and after closure of a Danish ship-yard: A 2year follow-up study. Soc Sci Med 1986;22:107-9.

15 Iversen L, Klausen $\mathrm{H}$. The closure of Nordhavn shipyard. Copenhagen Institute of social medicine, Kobenhavns Universitet, 1981. (Publikation 13. FADL.)

16 Jenkins R, Macdonald A, Murray J, Strathdee G. Minor psychiatric morbidity and the threat of redundancy in a professional group. Psychological Medicine 1982;12:799-807. 
17 Grayson JP. The closure of a factory and its impact on health. Int J Health Serv 1985;15:69-93.

18 Beale N, Nethercott S. Job-loss and family morbidity: a study of a factory closure. J R Coll Gen Pract 1985;35:510-4.

19 Beale N, Nethercott S. Job-loss and health-the influence of age and previous morbidity. J $R$ Coll Gen Pract 1986;36: 261-4.

20 Beale N, Nethercott S. Job-loss and morbidity in a group of employees nearing retirement age. J $R$ Coll Gen Pract 1986;36:265-6.

21 Beale N, Nethercott S. Job-loss and morbidity in married men with and without young children. $J R$ Coll Gen Pract 1986;36:557-9.

22 Beale N, Nethercott S. Job-loss and morbidity: the influence of job-tenure and previous work history. $J R$ Coll Gen Pract 1986;36:560-3.

23 Beale N, Nethercott $S$. The health of industrial employees four years after compulsory redundancy. $J R$ Coll Gen Pract 1987;37:390-4.

24 Beale N, Nethercott $S$. Certificated sickness absence in industrial employees threatened with redundancy. $\mathrm{Br} M e d \mathrm{~J}$ 1988;296:1508-10.
25 Beale N, Nethercott $S$. The nature of unemployment morbidity. 1. Recognition. J R Coll Gen Pract 1988;38:197-9.

26 Beale N, Nethercott $S$. The nature of unemployment morbidity. 2. Description. J R Coll Gen Pract 1988;38:200-2.

27 Iversen L, Sabroe S, Damsgaard MT. Hospital admissions before and after shipyard closure. Br Med J 1989;299:1073-6.

28 Iversen L, Sabroe S. Participation in a follow up study of health among unemployed and employed people after a company closedown: drop outs and selection bias. J Epidemiol Community Health 1988;42:396-401.

29 Piachaud D. Disability, retirement and unemployment of older men. Journal of Social Policy 1986;15:145-62.

30 Grayson JP. Reported illness after a CGE closure. Can J Public Health 1989;80:16-9.

31 Withington J, Wybrow P. After the ships went down. New Society 1988;83:13-6.

32 Withington J, Hanson S, Peaker C. Shutdown. Thames Television PLC 1988.

Accepted 2 July 1990

\section{Vancouver style}

All manuscripts submitted to the $B r J$ Ind Med should conform to the uniform requirements for manuscripts submitted to biomedical journals (known as the Vancouver style)

The $\mathrm{Br} J$ Ind Med, together with many other international biomedical journals, has agreed to accept articles prepared in accordance with the Vancouver style. The style (described in full in Br Med J, 24 February 1979, p 532) is intended to standardise requirements for authors.

References should be numbered consecutively in the order in which they are first mentioned in the text by Arabic numerals above the line on each occasion the reference is cited (Manson ${ }^{1}$ confirmed other reports $\left.{ }^{2-5} \ldots\right)$. In future references to papers submitted to the $\mathrm{Br} J$ Ind Med should include: the names of all authors if there are six or less or, if there are more, the first three followed by et al; the title of journal articles or book chapters; the titles of journals abbreviated according to the style of Index Medicus; and the first and final page numbers of the article or chapter.

Examples of common forms of references are:

I International Steering Committee of Medical Editors. Uniform requirements for manuscripts submitted to biomedical journals. Br Med J 1979;1:532-5.

2 Soter NA, Wasserman SI, Austen KF. Cold urticaria: release into the circulation of histamine and eosino-phil chemotactic factor of anaphylaxis during cold challenge. N Engl J Med 1976;294:687-90.

3 Weinstein L, Swartz MN. Pathogenic properties of invading micro-organisms. In: Sodeman WA Jr, Sodeman WA, eds. Pathologic physiology: mechanisms of disease. Philadelphia: W B Saunders, 1974:457-72. 